\title{
Agile Project Management In Non-Software SECTORS DuRING TurbulENT Times
}

\author{
Nabeel T. Alsohybe ${ }^{1}$ and Nashwan Sabrah ${ }^{2}$ \\ ${ }^{1}$ Department of Information Technology, Sana'a University, Sana'a, Yemen \\ ${ }^{2}$ The School of Business, Lebanese International University, Sana'a, Yemen
}

\begin{abstract}
Scholars have viewed Agile Project Management APM as a prominent solution for software and nonsoftware innovative institutions to cope with its unstable environment. APM has been tested in the software field and proven to be successful. Since 2015, there is ongoing war in Yemen that negatively affects most sectors including the business and microfinance sectors. Social Fund for Development SFD, the microfinance industry leader in Yemen, sought solutions for enhancing the Microfinance Institutions MFIs capabilities during the current environment turbulence. This research investigates any possible advantages in adopting APM in the microfinance sector, out of software domain. A qualitative method was used to conduct the research. three microfinance pioneers were selected and 11 professionals from all management levels were interviewed. In addition, three workshop discussions with 22 members of product development teams were held. The study found that adopting APM would help these MFIs to enhance their resilience by bridging the identified gaps and challenges.
\end{abstract}

\section{KEYWORDS}

Agile Project Management, Traditional Project Management, Product development, Social Fund for Development, New Product Development.

\section{INTRODUCTION}

Since the 60s, many firms in different business domains use New Product Development method NPD for their products innovation [1]. The objectives of NPD process are to help in 1) identifying business opportunities through envisioning, 2) developing new products, and 3) to deliver products to the market [2], [3].

Furthermore, turbulent business environment or market dynamism increases the business uncertainty which challenges organization resilience to sustain its original level of performance or achieve new stable one [4]. Also, a Project Management Institute PMI study showed that the lack of organizational capabilities to respond effectively to its environment changes- lack of agility, is the common characteristics of the low performer organizations which causes a high rate of projects failure and money losses [5]. Therefore, firms call for new development model [6], [7].

Recently, there has been growing interest in APM as a lightweight and flexible way of managing the software development projects through short iterative cycles [8]. Moreover, literature views APM as a prominent solution for the agility challenges that face the traditional NPD firms in software and non-software domains [9]- [11].

Since the beginning of 2015, Yemen entered a political conflict that became a major regional war crisis. As a result, this war made the Yemeni business environment unstable and more challenging, negatively affecting MFIs operation performance [12] Causing them to encounter high financial losses [13] which added to their challenges in responding to their customer's demand [14]- [17]. 
Although MFIs are important tools for combating poverty and improving the well-being of many poor people, literature indicates that Yemeni MFIs face challenges in responding to their customer's demand [15], [17]. 22\% of MFIs' potential customers, Small and Medium Enterprises sizes SMEs did not find loans that were appropriate to their needs. In addition to that, $38 \%$ of borrowers claimed that loans size was not enough [17]. Moreover, Alshebami and Kandare [15] listed the lack of innovations, and customer-driven products as the main MFIs challenges [15].

Jakobi et al. [18] in their study of "Understanding National Culture's Influence on Product Innovation Approaches" calls researchers for more investigation in the field of project management agility within microfinance context which had less attention from the academic studies [18]. Furthermore, only a few academic studies have been done in the area of Agile project management within the NPD context outside the software development industry [19].

This paper is based on a case study of three Yemeni MFIs constricted as a response on a call from the microfinance industry leader in Yemen SFD, who sought solutions for enhancing the MFIs capabilities to cope with current environment turbulence. All selected institutions are supported by SFD, involving in developing new microfinance products.

The Paper sough answer to the main question: How could APM help MFIs during current turbulent time?

To answer this question, this paper presents a set of advantages identified through interviews and workshops from three MFIs. The paper focuses on challenges experienced in relation to several management levels and the possible APM interventions to overcome these challenges. The actual implementation of APM are not included in this paper.

\section{THEORETICAL BACKGROUND}

This section covers the concepts of New Product Development, Agile Method, and Resilience.

\subsection{Innovation Process- New Product Development NPD}

The product development process is seen from its top level as a set of activities applied by people who are involved in the product development function to 1) envision, 2) develop, and 3) deliver a product to the market [2], [3].

In microfinance industry, M. Brand [20] suggested a four- stage process of product development: 1) evaluation and preparation, 2) prototype design and development, 3) pilot testing, and 4) product launch. In addition, CGAP [21] training manual and Wright et al [22] article, described a Five-Stages process model: First, Evaluation and Preparation. Second, Market Research. Third, Concept/Prototype Design. Fourth, Pilot Testing. Fifth, Product Launch and Rollout.

Moreover, scholars recognized project management as a process within the product development to organize work and optimize high levels of innovation [3], [23] where the NPD methods represent the macro-process and the project management approach is the micro-process within the product development process [24]. Furthermore, two main types of project management have been recognized by literature that have been adopted by firms' management within its NPD Model for several business reasons: 1) Traditional Project Management TPM and 2) Agile Project Management APM [23], [24].

According to Sutherland and Ahmad [25], the traditional project is typically organized as several steps of grouped activities where the work is moving sequentially through each step, and when changes are needed in a previous step, then that step and all following steps are sequentially re- 
executed. TPM starts with heavy planning activities to come up with a project's detailed plan by predicting all individuals' tasks required to complete the project. The downwards sequence of work movement known as the waterfall approach [25].

Furthermore, NPD projects that adapted TPM are seen by scholars as plan-driven method start with heavy planning efforts then strict to the plan during the whole project. This method is working well under the condition of predictable and stable environments, where this condition is not available for many firms due to the unstable environments. As a result, many firms involved in developing products in a dynamic market are faced with several challenges in their projects which can be summarized as lack of 1) the ability to adapt, 2) the ability to accelerate, and 3) the ability to cope with the complexity and uncertainty [10].

\subsection{Agile project management APM}

Agile project management APM is known among software and non-software professionals as a lightweight and flexible way of managing software development projects through short iterative cycles [8]. Moreover, according to Ovesen [10], the word "Agile" in the English language is" an attribute often associated with animals like the big cats. Like being alert and responsive. Also, well-coordinated and quick when it comes to movement" [10]. Furthermore, Agile software development, Agile product development, Agile project management, or Agile Methods are terms commonly used by researchers in the field of software development [26].

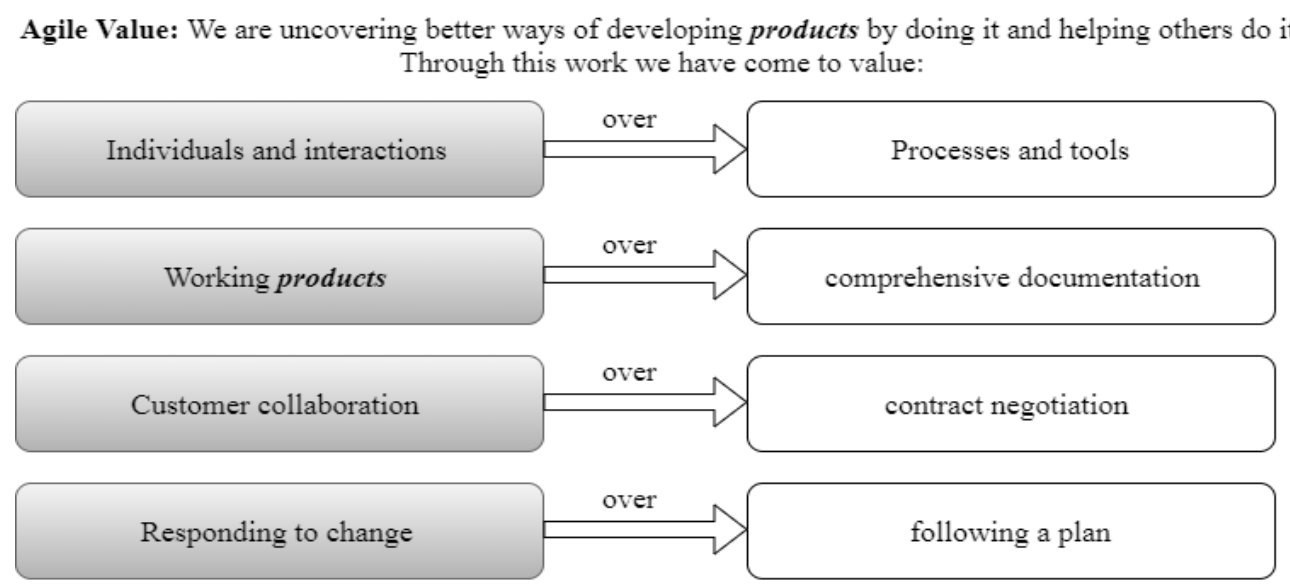

That is, while there is value in the items on the right, we value the items on the left more.

Figure 1 Agile Value. Source: adapted from [27].

Therefore, APM is a software development concept represents a philosophy and a mind-set or a way of thinking that elaborated by applying certain practices that links to agile core values, see Figure 1, and principles described in the Agile Manifesto [28] in terms of becoming strategically capable to respond to change, to balance flexibility and linearity, to encourage innovation, and to strengthen organizations in a changing and uncertain environment [29].

According to Highsmith [29], APM process usually starts by creating a simple business case or product vision which has enough description to start the project. Based on the product vision and the team knowledge, team Speculates the product specifications. The second step of APM process is to go through short iterations to develop the product, and during these iterations, the uncertain requirements evolved as new knowledge that can be gained through the team experimentation and 
International Journal of Software Engineering \& Applications (IJSEA), Vol.10, No.1, January 2019 collaboration with customers and stakeholders. Based on these experiments, the team continually incorporate adaptive actions into the next iteration. Finally, the project ends when the result satisfied the customers [29].

APM represented by several methods that recognized as an agile method such as Scrum Framework, and Extreme Programming XP [30]. These methods become widely accepted because of their usefulness, easiness, and maturity characteristics [31].

Moreover, Robert G. Cooper and Sommer [32] mentioned that Scrum is the most applicable method to be used in non-software products. Thus, this research paper will only go through Scrum explanation later-on in this chapter and uses Scrum as APM's representative for this study. Section 2.5 provide brief information about Scrum.

\subsection{Comparison between Traditional and Agile Methods}

There are some conditions that make APM a recommended approach over TPM and conversely, for example when the market environment is dynamic, the APM is recommended. While if the market is stable and predictable then TPM is the better [34]. Table 1 summarizes the conditions that drive the decision towered using APM or TPM; adapted from [34].

Table 1 Conditions that drive the decision towered using APM or TPM

\begin{tabular}{|l|l|l|}
\hline \multicolumn{1}{|c|}{ Condition aspect } & \multicolumn{1}{|c|}{ APM } & \multicolumn{1}{c|}{ TPM } \\
\hline Market environment & Unpredictable or dynamic & Tend to be Stable and Predictable \\
\hline Customer involvement & $\begin{array}{l}\text { Customers Collaboration and } \\
\text { quick feedback are important }\end{array}$ & Not important \\
\hline Innovation & $\begin{array}{l}\text { Cope with Project complexity, } \\
\text { requirements changes, and } \\
\text { accelerating the speed to } \\
\text { market are important and the } \\
\text { Cross-function collaborative } \\
\text { team is substantial. }\end{array}$ & $\begin{array}{l}\text { The Solutions are clear. } \\
\text { Requirements are predictable. } \\
\text { Repeated project. } \\
\text { Project goals can be achieved } \\
\text { sequentially through functions } \\
\text { coordination. }\end{array}$ \\
\hline Project Criticality & $\begin{array}{l}\text { Leaming from mistakes is } \\
\text { valuable }\end{array}$ & $\begin{array}{l}\text { Mistakes may cause a great } \\
\text { damage }\end{array}$ \\
\hline
\end{tabular}

\subsection{Adopting APM in Non-Software Organizations}

Conforto et al [19]. connected a study to investigate the possibility of adopting APM out of software domain. Six management practices and ten agile enablers factors were used in their study. They have been extracted from several Agile studies to assess 19 companies. There were 48 responders to identify the presence of APM practices and the enablers in companies from different industry sectors [19].

Conforto et al [19], defined APM practices as a group of management practices that clearly differentiate the use of the APM approach from other approaches. In addition, APM Enablers are the critical factors that, if any, will make the use of APM practices, tools, and techniques favourable. Some of these critical factors can include, but not limited to, people competencies, team characteristics, structure, organizational culture, and available resources, uncertainty of technology, and market characteristics [35] which are summarized in Table 2. 
Table 2 AMP enablers.

\begin{tabular}{|l|l|l|}
\hline$\#$ & \multicolumn{1}{|c|}{ Enabler aspects } & \multicolumn{1}{c|}{ APM approach } \\
\hline 1 & Organizational structure type & Project-oriented is preferable \\
\hline 2 & Multidisciplinary project teams & Multi-skilled and cross-functions teams \\
\hline 3 & NPD process formalization level & $\begin{array}{l}\text { Partially standardized. For having a room for } \\
\text { a better adaptation to different types of } \\
\text { projects }\end{array}$ \\
\hline 4 & Customer/stakeholder involvement in NPD & Involved with influence in the project plan \\
\hline 5 & $\begin{array}{l}\text { Supplier/partner involvement in NPD } \\
\text { process }\end{array}$ & $\begin{array}{l}\text { Involved in all project phases to obtain } \\
\text { immediate feedback when teams needed }\end{array}$ \\
\hline 6 & Project team members' experience & At least two years of experience \\
\hline 7 & Project manager experience & At least two years of experience \\
\hline 8 & Project team size & Small team, up to eight members, is preferable \\
\hline 9 & Project team dedication time for the project & Full time or more than 75\% is preferable \\
\hline 10 & Project team location & At the same room \\
\hline
\end{tabular}

*Adapted from [19]

Additionally, Sommer et al. [7] investigated seven manufacturing companies in a variety of industries and identified several challenges that drive these seven industrial companies to implement Agile/ NPD hybrid processes, and in return six of these companies gained substantial performance benefits from it [7].

After that, R. Cooper and Sommer [32] expanded the explanation of the Agile/ NPD hybrid based on the same cases and summarized the benefits as the following:

- Fast response to changing product or customer requirements

- Reinforce pro-active and effective voice-of-customer (VOC)

- Deals with the resourcing issue such as dedicating team members

- Process Acceleration and productivity enhancement [32]

\subsection{Scrum framework}

Scrum is regarded as one of the process models adhering to the agile manifesto. Takeuchi \& Nonaka first mentioned the concept of Scrum in relation to development as early as in 1986 to describe the similarities between the strategy used in Rugby and product development in several companies in Japan - both are adaptive, quick, self-organizing, and have few rests [11]. Jeff Sutherland with Ken Schwaber announced Scrum as a formal process at OOPSLA'95 [33]. The Scrum emphasis is on an empirical process rather than on a defined process as well as emphasizes self-organizing teams [33]. In contrast to other agile methods, Scrums are intended to be a project management approach through the development process [30].

According to the official Scrum Guide, projects in Scrum framework managed by a selforganizing and cross-functional team called the scrum team which contains three roles; 1) Product owner role, 2) Development team role, and 3) Scrum-master role [33]. Scrum framework includes five formals and Time-boxed ceremonies called events which means these events are predefined and locking the activity into specific time period illustrated in Table 3 [33]. 
Table 3. Scrum ceremonies summary.

\begin{tabular}{|l|l|}
\hline Ceremonies & \multicolumn{1}{|c|}{ Description } \\
\hline Ceremonies characteristics & $\begin{array}{l}\text { - For the team to discover and learn from his success and his } \\
\text { fault, and find something to be adapted to improve his } \\
\text { performance. } \\
\text { Includes development sprints, and four meetings } \\
\text { - Predefined and Time-boxed }\end{array}$ \\
\hline The sprint & $\begin{array}{l}\text { One month maximum iterative activity where the development } \\
\text { team is doing the actual development efforts }\end{array}$ \\
\hline ScrumSprint planning & $\begin{array}{l}\text { A meeting that conducted at the beginning of each iteration for } \\
\text { maximum eight hours per month where the team sets the goal of } \\
\text { the sprint and select the requirements from the product backlog to } \\
\text { be executed in the sprint. }\end{array}$ \\
\hline Daily stand up meeting & $\begin{array}{l}\text { A daily meeting during the sprint takes } 15 \text { minutes' maximum at } \\
\text { the beginning of the day. The team communicates what has been } \\
\text { done yesterday, and what needs to be done in today, as well as } \\
\text { any obstacles are shown. }\end{array}$ \\
\hline Sprint-review & $\begin{array}{l}\text { A meeting held when a sprint completed, for a maximum of four } \\
\text { hours per month. The team reviews the development result with } \\
\text { the customers and other stakeholders to obtain formal feedback. }\end{array}$ \\
\hline Sprint-retrospective & $\begin{array}{l}\text { A meeting held when a sprint completed - after the sprint review- } \\
\text { and takes a maximum of three hours per month. The team inspect } \\
\text { his performance and set a plan for improvements to be applied in } \\
\text { the next sprint. }\end{array}$ \\
\hline
\end{tabular}

Source: Summarized from the official Scrum Guide [33]

In addition to that, the Scrum framework includes three official tools called artefacts used to represent the work which is the backlog, the definition of done - DOD, and Burn-down chart [33] Also, there is unofficial artefact called The Task Board or the Scrum Board, that scrum teams are commonly used [10]. The Task Board is a visual communication tool that mainly helps to visualize the project tasks details and status by using post-it notes and a whiteboard [10].

\subsection{Resilience and performance}

In turbulent times like in nature crisis time, business environment inherently becomes unstable where organizations need to cope with such turbulence and the changes inherent [4]. Therefore, business environment turbulence can demonstrate as demands and customer's requirement changes, market direction changes, and tools and technology changes which requires a new business management way because previous business strategies and practices would no longer be aligned with the actual environment which involved high ambiguity due to a lack of enough market information [36], [37]. Also, the high competition level may affect firm's market position and influence the need for change and adapt [10].

Another important challenge is operation disruptions or unexpected disturbances that affect firm's supply chain operation or firm's performance [4], [37].

Therefore, the responsiveness strategy for the customers' need in terms of providing value to the customers through products innovation, and the lead time to market strategy are the suitable strategies required to cope with market changes and to obtain better performance and resilience in turbulent times [4], [10], [37].

Carvalho et al. [37] argued that agility and resilient are two separate concepts; where agility is being able to respond to changes very quickly, while the resilience is the ability to recover after a disturbance; the combination of both concepts leads to better performance [37]. In contrast, McCann et al. [38] found a strong correlation between the two concepts, agility, and resilience. In addition, Wieland and Marcus [4] argued that resilience is the ability of a supply chain to cope 
with changes which formed by two dimensions or component: 1) agility as reactive strategy to rapidly respond to change by adapting the initial stable state, and 2) robustness as proactive strategy to resist change without adapting the initial stable configuration where robustness requires predictions of change prior to occurrence [4]

Therefore, according to Wieland and Marcus [4], achieving agility dimension can occur by achieving: 1) Visibility for better identification of changes, and 2) Speed for a faster response to changes

Moreover, Wieland and Marcus [4] empirically proved that communicating, and cooperating for sharing information with suppliers, customers and other stakeholders have a positive effect on visibility and speed as well as the resilience overall, in addition improving agility contribute to enhancing firms' responsiveness to their customer by providing more customer value as an essential performance measurement that would be gained through different aspects but mainly: 1) conformance to customer specifications and 2) conformance to customers' satisfaction [4].

\section{RESEARCH METHODS}

This study is primarily based on the qualitative case study method. The qualitative study research is used when the problem needs to be explored through studying individuals to obtain their understanding regarding a phenomenon or an issue where the phenomena cannot be separated from its context [39], [40]. Qualitative research is also used when quantitative measures and statistical analyses do not fit the problem [39], and thus, to investigate a phenomenon in a real-life within its context where behaviour controlling is not required, and quantitative measures are not mature yet [19], and the qualitative case study approach is considered as a suitable one according to Creswell and Yin [39], [40].

The institutions in this study have been selected based on the following criteria: 1) most recently have been involved in developing new financial products, 2) willing to provide the required access to all relevant data and individuals, and 3) showing interest on the research subject. The institutions are identified through an official SFD list of registered MFIs. Due to the war circumstances in Yemen and the budget and time limits of this research work, this study limits the potential cases to those institutions located in the Capital of Yemen, Sana'a to partially fulfil the accessibility criterion condition. The researchers interviewed 11 employees from different levels of management, see Figure 2, and conducted three workshops with 22 participants who are involved in product development project recently.

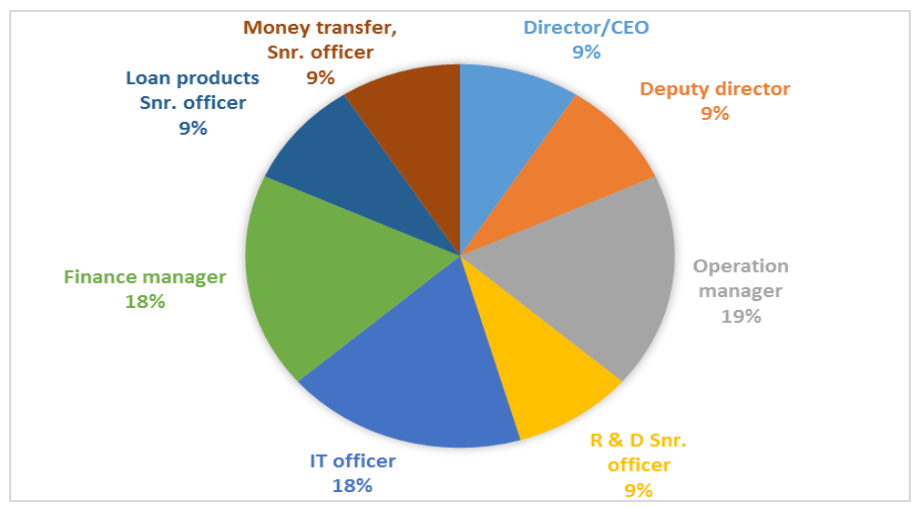

Figure 2. The interviewees job positions 
International Journal of Software Engineering \& Applications (IJSEA), Vol.10, No.1, January 2019

Since this study is based on qualitative methodology, triangulation was used for the collection of the primary data. The term Triangulation refers to the combining of several research methods in order to overcome the weaknesses of a single-shot approach [41]. By considering Yin [40] recommendations, the researchers take into their consideration to reduce the threats regarding the study validity and reliability during all study stages. Table 4 summarizes the validity and reliability strategies of this research based on [40]

Table 4. Summary of the study validity and reliability strategies

\begin{tabular}{|c|c|c|}
\hline \# & Item & Description \\
\hline \multirow[t]{4}{*}{1} & Validity: & \\
\hline & Multiple sources of data & $\begin{array}{l}\text { Using semi-structured interview and documents review } \\
\text { to triangulate the evidence as well as conducting three } \\
\text { workshops. Also by replicating the study on three MFIs. }\end{array}$ \\
\hline & Chain of evidence & $\begin{array}{l}\text { Linking the interview guide questions to the case study } \\
\text { objectives, which are linked to the result evidence. }\end{array}$ \\
\hline & Generalization & Not to be generalized out of the case studies context \\
\hline \multirow[t]{3}{*}{2} & Reliability & \\
\hline & Case study protocol & $\begin{array}{l}\text { Constructing interviews questions from well-known } \\
\text { authors' articles and articles published in the respectful } \\
\text { magazines. Developing the interview protocol and } \\
\text { involving several ethical aspects such as privacy and } \\
\text { voluntary participation. participants are reviewing the } \\
\text { interview transcript. }\end{array}$ \\
\hline & Case study database & Recording all interviews and transcripts using Atlas-Ti \\
\hline
\end{tabular}

Therefore, the current study's data collection is triangulated by using semi-structured interviews [39], and workshop discussions [42]. According to Ørngreen, R., and Levinsen, K. [42], workshops become part of the research design and the data collection, that can be artful if they were combined with other empirical methods. The second data source is based on literature reviews and case study documents review that includes process manuals, project files, and internal policies.

An interview guide is used, where its questions have been linked to the current study objectives and model as well as a pilot test conducted with one Yemeni MFI. The interviews were digitally recorded, transcript and saved using Atlas-Ti application. Data analysis started, after reviewing transcripts with participants, by quotation and coding process conducted using Atlas-Ti for each case. Second, conducting cross-cases comparative analysis, identifying the overall themes and consulting the literature for drawing the results. See Table 5 for more information about the interview guide.

Table 5. Summary of the interview guide

\begin{tabular}{|l|l|l|}
\hline Reference & Objective & Main interview questions \\
\hline $\begin{array}{l}{[6],[10],} \\
{[4],[37]}\end{array}$ & $\begin{array}{l}\text { Assessing External } \\
\text { forces and the need for } \\
\text { agility }\end{array}$ & $\begin{array}{l}\bullet \\
\text { What are the external forces that have } \\
\text { affected your institution during the current } \\
\text { crisis and war? } \\
\text { - } \begin{array}{l}\text { How would you describe the demand for } \\
\text { microfinance products during the war? }\end{array}\end{array}$ \\
\hline $\begin{array}{l}{[19],[10],} \\
{[6]}\end{array}$ & $\begin{array}{l}\text { Assessing the product } \\
\text { development process }\end{array}$ & $\begin{array}{l}\text { Have you participated in the development of } \\
\text { innovative or complex products recently? If } \\
\text { yes? Can you mention the latest products? }\end{array}$ \\
\hline
\end{tabular}


International Journal of Software Engineering \& Applications (IJSEA), Vol.10, No.1, January 2019

\begin{tabular}{|l|l|l|}
\hline & & $\begin{array}{l}\text { - } \begin{array}{l}\text { How do you develop your products? Briefly } \\
\text { explain the development process in your } \\
\text { institution? Please }\end{array} \\
\text { Regarding the products you mentioned to me } \\
\text { earlier - what are the most important } \\
\text { problems or challenges you faced in those } \\
\text { projects? }\end{array}$ \\
\hline$[4],[37]$ & $\begin{array}{l}\text { Assessing the } \\
\text { institution's resilience }\end{array}$ & $\begin{array}{l}\text { What has helped you to survive? What has } \\
\text { negatively affected your ability to } \\
\text { withstand? }\end{array}$ \\
\hline$[10],[4]$, & $\begin{array}{l}\text { Assessing the } \\
\text { suggested solution }\end{array}$ & $\begin{array}{l}\text { Do you think there is a need to change your } \\
\text { project management method? And why? } \\
\text { What are the most interesting practices in } \\
\text { APM, according to what you have seen in } \\
\text { the workshop? }\end{array}$ \\
\hline
\end{tabular}

\subsection{Case Overview}

Cases profile information shown in Table 6. all cases are focusing on providing Islamic loans products, and only case 1 has additional products which are micro-saving and money transfer. By comparing the performance indicators, case 2 is the lowest performer with Operational SelfSufficiency OSS $=41 \%$, Financial Self-Sufficiency FSS $=30 \%$. Also, only one institution is following a written process guideline which is case 1 .

Table 6. Cases profiles overview

\begin{tabular}{|l|l|l|l|}
\hline Context elements & Case 1: The Bank & \multicolumn{1}{|c|}{$\begin{array}{c}\text { Case 2: The } \\
\text { program }\end{array}$} & Case 3: The foundation \\
\hline Establishment year & 2009 & 2001 & 2000 \\
\hline Products & $\begin{array}{l}\text { Islamic loans, Micro- } \\
\text { saving, and money } \\
\text { transfer }\end{array}$ & Islamic loans only & Islamic loans only \\
\hline Employees No. & 177 & 80 & 104 \\
\hline Branches & 18 & 5 & 10 \\
\hline Portfolio Sep-2017 & 2,318 Million YR & 363 Million YR & 434 Million YR \\
\hline OSS Sep-2017 & $185 \%$ & $41 \%$ & $134 \%$ \\
\hline FSS Sep-2017 & $78 \%$ & $30 \%$ & $109 \%$ \\
\hline NPD method & $\begin{array}{l}\text { In-house guideline } \\
\text { document based on } \\
\text { CGAP, 4 stages }\end{array}$ & $\begin{array}{l}\text { Ad-hoc, no guideline } \\
\text { document, 3 stages }\end{array}$ & $\begin{array}{l}\text { No guideline document } \\
-4 \text { stages }\end{array}$ \\
\hline Development team & Cross function & Cross function & Cross function \\
\hline
\end{tabular}

\section{RESUltS}

For this paper, the authors reanalysis each case and provide another point of view of the main study result by re-categorizing its finding result. The reason for that is providing more focused result regarding this paper's scope. As a result, all institutions are not aware about APM but in response to the current turmoil, two of them start to adapt several ad-hock practices that improved their agility. Therefore, after Scrum fundamentals presentation, and during the workshop 
discussion most participants from these two institutions, claimed that their current practices were close to Scrum practices. In the following analysis and discussion, these new practices were considered. The following list present the main categorization aspects that challenges the institutions for effectively respond to current environment pressure as well as the possible APM interventions to overcome these challenges and obtain better resilience and performance.

\section{External challenges:}

1. Mainly change in demand and competitive landscape, enforce microfinance cases to newly adopt a market responsiveness strategy. Internal challenges:

1. Low Visibility mainly of project requirements, process visibility, and goals and tasks priority

2. Difficulties to speed up the progress mainly in meeting project deadlines since teams are dissatisfied due to the high workload and suffered from long overtime hours.

3. Low innovation capabilities mainly in dealing with project's complexity.

\section{Recommended APM practices:}

1. Using visual tools such as a whiteboard, sticky notes, and drawing to communicate the project plan.

2. Using the iterative planning approach.

3. Updating the project plan in a fixed and short time period such as weekly or biweekly.

Most of the investigated institutions have a good chance to succeed in adopting APM, but five main enablers have been recognized as the less presented factors which are:

1. Organizational structures are not a project-oriented structure.

2. Partial NPD process formalization is not existing.

3. Supplier/partner are not involved in all stages

4. Project team dedication time for the project is lower than $75 \%$ - the recommended time.

5. Team are not locating at the same room

\section{ANALYSIS AND DISCUSSION}

Current war crisis has caused several market changes that threaten the business continuity of the investigated institutions. by exploring the external environment forces that affect the operation of study cases to bring insight into the external pressures that the studied cases faced during the current crisis. Then, investigating the strategies of the studied cases to deal with these pressures to determine any alignments between the external pressures and institution strategies that can make the need for agility a rational idea.

In all cases, the external pressure drives the institutions to change their strategies to be more responsive regarding the market need. The study shows that more than 15 different type of challenges exist. These challenges include issues related to the external environment from the perspective of market changes, and issues related to the resilience capabilities. As mentioned before, this paper specifically focused on the agility component of resilience model and related challenges from the perspective of product development agility. Within this framing the main challenges are analysed and discussed. 


\subsection{External Challenges - That Drive the Need for Agility}

The themes of the external pressures come from the decline of people's income, security, and safety issues, which causes changes in demand and competition level in some areas and products. This study found a rise in the level of competition between the MFIs, contrary to what was expected, since the literature indicated that the level of competition in most of the microfinance markets is low [43], [44]. The reason for this change in the competition level is due to the crisis attributes as what the interviewees pointed to, such as they are looking for the safe and the lowrisk areas, the damage to many good customers and the entry of commercial banks to compete in one of the microfinance products. Therefore, MFIs started to compete in the low-risk areas and around the good clients. Also, the good financial return from the social money transfer maybe encouraged the commercial banks to enter the market. Therefore, all cases adopt newly several strategies to cope with these external forces.

The main strategy seen to cope with changes in demand and competition level was responding to the market changes through products innovation. Also, two cases adopt contingency plan as the main strategy to cope with any disruption for their operations. Table 7 summarizes the external challenges themes.

Moreover, innovating new products by modifying existing ones or adjusting some products features has been used to respond to market changes, which allowed the institutions to generate more revenue and retain its important clients. interviewee 1-p3: "80\% of our revenues in this year came from new products". Furthermore, all cases avoid developing totally new products in terms of new to the market. Interviewee 1-p3: "We rely very heavily on market surveying for the categories of clients who we normally work with. It means it is very dangerous when you are in a country of conflict and war it is difficult to start a new product offered to a new category".

Noticeably, business environment turbulence that causes changes in demands and market direction requires a new business management approach because previous business strategies and practices would no longer be aligned with the actual environment which involves high ambiguity due to a lack of enough market information [36].

Table 7 External challenges - agility need

\begin{tabular}{|l|l|l|l|}
\hline External Challenge & Case 1: The Bank & $\begin{array}{l}\text { Case 2: The } \\
\text { Program }\end{array}$ & $\begin{array}{l}\text { Case 3: The } \\
\text { Foundation }\end{array}$ \\
\hline The need for agility \\
\hline Drivers & $\begin{array}{l}\text {-Demand Changes } \\
\text {-Operation } \\
\text { disruptions } \\
\text {-Market uncertainty } \\
\text {-Competition }\end{array}$ & $\begin{array}{l}\text {-Demand Changes } \\
\text {--Market uncertainty }\end{array}$ & $\begin{array}{l}\text {-Demand Changes } \\
\text {-Competition } \\
\text {-Operation } \\
\text { disnuptions } \\
\text {-Competition }\end{array}$ \\
\hline Strategies/ Goals & $\begin{array}{l}\text { - Responding to the } \\
\text { market changes } \\
\text { - Emergency plan }\end{array}$ & $\begin{array}{l}\text { - Responding to the } \\
\text { market changes }\end{array}$ & $\begin{array}{l}\text { - Responding to the } \\
\text { market changes } \\
\text { - Emergency plan }\end{array}$ \\
\hline
\end{tabular}

\subsection{Internal challenges}

By asking the interviewees about the main challenges or problems they faced recently in their projects, the interviewees identified several obstacles that recently challenge development projects progress. In Case 1, the interviewees highlighted challenges in acquiring the necessary 
market information. Due to the unavailability of updated market studies, the institution faces difficulties in conducting such study by itself because of the geographic fragmentation of the targeted groups where each targeted area has different requirements and the need to obtain many security permissions which highly increase the project cost since the alternatives are limited. In Case 3, the interviewees refer to several challenges such as understanding current development process as only few key persons are responsible and any changes in the plan should be approved by them. In addition, the team faced several failures in designing innovative products due to the lack of understanding the sharia low requirements since the sharia comity usually involved in the last stage of the projects.

Moreover, the lack of having shared understanding of projects goals and tasks priority between all departments that involved in the projects impedes the projects progress in Case 1. Interviewee 1p5: "The most important problem is not to sense the importance of the project or what we do. As we face some difficulties with some departments. Also, due to the lack of full-time work in the project, so we must work outside the working hours and sometimes to late times at night. This may require doubling the working hours".

Furthermore, in all cases, teams struggle to meet projects deadlines and suffer from work overload as well as the long overtime hours. Table 8 shows themes category and the internal challenges Comparison.

Noticeably, all cases mainly innovate new products by modifying old ones and avoid any opportunities that required totally new innovative products. The innovation capacity limits, requirements ambiguity, demotivated team, and lack of several stakeholder involvements seen as main aspects that leads to limits their innovation capabilities.

Table 8. Comparison of the internal challenges

\begin{tabular}{|l|l|l|l|}
\hline Challenge Category & Case 1: The Bank & $\begin{array}{l}\text { Case 2: The } \\
\text { Program }\end{array}$ & $\begin{array}{l}\text { Case 3: The } \\
\text { Foundation }\end{array}$ \\
\hline Low Visibility & $\begin{array}{l}\text { - Increases in the } \\
\text { cost of acquiring } \\
\text { the necessary } \\
\text { market } \\
\text { information } \\
\text { - No Shared } \\
\text { understanding of } \\
\text { project goals and } \\
\text { tasks priority }\end{array}$ & $\begin{array}{l}\text { - No product } \\
\text { specialist } \\
\text { - No development } \\
\text { guide }\end{array}$ & $\begin{array}{l}\text { - Process } \\
\text { invisibility. } \\
\text { - Can't easily } \\
\text { change project's } \\
\text { plan } \\
\text {-Lack of - } \\
\text { stakeholders } \\
\text { involvement }\end{array}$ \\
\hline $\begin{array}{l}\text { Difficulties to speed up } \\
\text { the progress }\end{array}$ & $\begin{array}{l}\text { - Meeting project } \\
\text { deadlines- } \\
\text { currently suffering } \\
\text { from } \\
\text { overload and the } \\
\text { long overtime } \\
\text { hours }\end{array}$ & $\begin{array}{l}\text { - Meeting project } \\
\text { deadlines- } \\
\text { currently suffering } \\
\text { from } \\
\text { overload work }\end{array}$ & $\begin{array}{l}\text { - Meeting project } \\
\text { deadlines- } \\
\text { currently } \\
\text { suffering from } \\
\text { work overload }\end{array}$ \\
& $\begin{array}{l}\text { Some Innovative } \\
\text { and complex } \\
\text { projects failed in } \\
\text { its last stage: due } \\
\text { to low }\end{array}$ & $\begin{array}{l}\text { Avoid complex } \\
\text { product innovation } \\
\text { due to its capacity } \\
\text { limits }\end{array}$ & $\begin{array}{l}\text { Some Innovative } \\
\text { projects failed in } \\
\text { its last stage: lack } \\
\text { of stakeholders' } \\
\text { involvement }\end{array}$ \\
\hline $\begin{array}{l}\text { Low innovation } \\
\text { capabilities }\end{array}$ & \multicolumn{2}{|l}{} \\
\hline
\end{tabular}


International Journal of Software Engineering \& Applications (IJSEA), Vol.10, No.1, January 2019

\begin{tabular}{|l|l|l|l|}
\hline Challenge Category & Case 1: The Bank & $\begin{array}{l}\text { Case 2: The } \\
\text { Program }\end{array}$ & $\begin{array}{l}\text { Case 3: The } \\
\text { Foundation }\end{array}$ \\
\hline & $\begin{array}{l}\text { requirements } \\
\text { accuracy, lack of } \\
\text { stakeholder } \\
\text { involvement }\end{array}$ & & $\begin{array}{l}\text { - Team } \\
\text { demotivated - } \\
\text { due to team } \\
\text { allowances } \\
\text { below the market } \\
\text { average. Work } \\
\text { by command }\end{array}$ \\
\hline
\end{tabular}

\subsection{APM possible intervention}

In response to the market turbulent, all cases adapt the strategy of responding to the market demand and competition changes by innovating new products as the essential strategy that helps the institution to resist the turbulence. In addition to that, it requires a new business management way and practices too, aligned with the new strategy and the actual environment [36]. Interviewee 2-p2: "I think that following a systematic mechanism will make the process take longer and we are now in an emergency situation and we need a quick intervention and the current mechanism provides this, I think it is the most appropriate. But in the long term, we need to work on both sides, but at the moment speed is important".

In two of the investigated cases, the development teams start new ad-hoc practices and adapt current process for obtaining better flexibility. For example, Case 1 has a well-documented guide for product development, but the team must bypass or add practices based on the project's nature, interviewee 1-p8: "Some changes are made, and the manual is sometimes overridden by the nature of the project. We may see that some steps are not necessary and are bypassed. And sometimes some steps are added that we see necessary even if they are not mentioned in the manual we created, we would innovate them". On the other hand, Scrum framework only provides a skeleton of the development process which contains a set of rules that control certain activities and allows firms and the self-managed team to include various processes and techniques to obtain better adaptation to different types of projects in the dynamic environment [10], [33].

According to several studies, APM can be adopted out of software field which help institutions cope with the environment changes and provide better customer response [19], [45]. This study found that it is a possibile for the investigated MFIs to adopt APM and gain benefits in terms of maintaining their performance and resilience.

This study used Conforto et al. [19] model to identify the APM practices and enablers gaps which only considers the most six important practices from 98 practices related to APM and the most 10 important enablers from 41 enabler factors related to APM; which this study finding limits to these most important practices and enablers according to Conforto et al [19]. By comparing the APM enablers existing between the three cases, see Figure 3, case 1 has eight enablers out of ten that are close to the APM enablers that required to favour the use of APM practices, tools, and techniques. Also, case 2 has seven out of ten enablers, and case 3 has six out of ten enablers. 


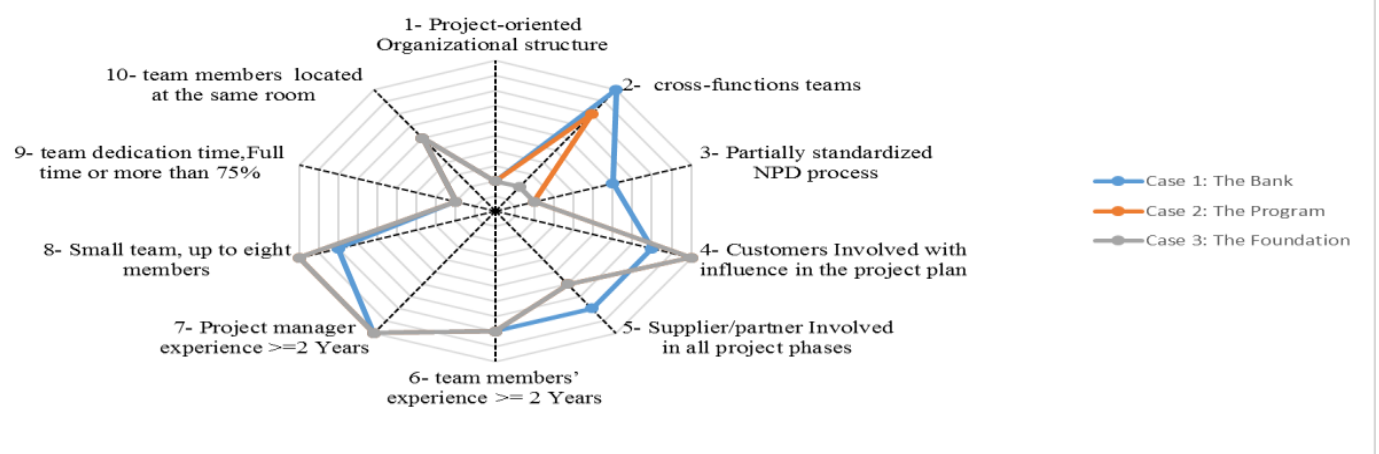

Figure 3. Comparison of the enabler factors

Thus, case 1 and case 2 are the most likely institutions to succeed in adopting APM while case 3 is a less likely institution to succeed. This result can partially explain why case 1 and 2 are most likely to manage their projects with flexibility.

Moreover, this study investigated the existence of the most APM practices according to Conforto et al. [19] And by comparing the APM practices gaps between the three cases, the practices of case 2 are the closest practices to APM practices since five practices out of six are Partially APM while case 1 has only three practices close to the APM practices and case 3 has only one practice close to the APM practices.

For providing more insight about how APM could contribute to overcome with the findings of the internal challenges, gaps in practices and enabler aspects linked to the internal challenges and literature explanations' evidences have been provided. As a result, using visual artefacts, applying the iterative planning approach and updating the project plan either weekly or biweekly, having project-oriented structure, partially standardizing the NPD process, dedicate the core team's time for more than $75 \%$ to one project, and locating team at the same room are the main factors that contribute to helping institutions to overcome innovation projects complexity by helping teams collaborate among themselves and share knowledge and expertise, which adds to their knowledge and innovation [10]. Also monitoring and updating the project plan weekly or bi-weekly following the iterative planning approach will contribute to accelerating development speed [10]. As an example, Figure 4 provide a visual summary of the gap in practices for all cases by using simple median and percentage calculation based on a scale from 0 to 4 where zero reflect Not Agile practices and four reflect Fully Agile practices.


Figure 4. Result's summary of the gap in APM practices 
Additionally, when core teams dedicate full time or more than $75 \%$ to one project, they will participate in increasing project progress [32]. Also involving customers, suppliers, and other stakeholders in all development stages will help to obtain faster feedback which helps in accelerating project speed [19]. Moreover, by adopting APM, overtime can be reduced by nearly two thirds in one year [46].

Furthermore, using visual artefacts, applying the iterative planning approach, and having a dedicated team will help the team to concentrate on the high priority customer requirements and only do work that adds value for the customer [19] which contributes to increasing the product quality and the customer satisfaction [47].

Therefore, when there are lacks market studies and much uncertainty that hinder teams' ability to understand the requirements, APM can help when applied at early stages or "fuzzy front end" of the innovation process stages such as finding an opportunity and envision stages. And by starting with a simple vision and executing these stages through multiple sprints- iterations- that allow high customer involvement, multiple tests, and the use of visual methods, which enable teams to overcome with the problem using trial and error approach [48].

From the perspective of the resilience theory, having the required visibility for better identification of changes and speed for a faster response to changes can be achieved by communicating and cooperating for sharing information with suppliers, customers, and other stakeholders [4]. APM contributes to improving visibility and speed mainly by using visual artefacts, applying the iterative planning approach, and involving customers, suppliers, and other stakeholders in all development stages that will help in improving communication, collaboration and information sharing as well as accelerating development speed [10].

Thus, for achieving better resilience and customer response this study recommends that the institutions in this study need to conceder several APM practices and enablers. Table 9 provides themes' summary of the cases' agility gaps linked to internal challenges theme and possible APM values.

Table 9. Main agility gaps linked to the internal challenges

\begin{tabular}{|c|c|c|}
\hline Gaps & APM Values & Internal Challenges \\
\hline \multicolumn{3}{|l|}{ APM Practices" gaps } \\
\hline $\begin{array}{l}\text { 2- Visual artifacts not used } \\
\text { to communicate the plan }\end{array}$ & \multirow{2}{*}{$\begin{array}{l}\text { Visual artifacts and iterative planning } \\
\text { approach help teams to Focuses on the } \\
\text { core problems and challenges and to } \\
\text { identify most valued aspects and } \\
\text { prioritizing them accordingly [19] }\end{array}$} & $\begin{array}{l}\text { Low Visibility; 1ow } \\
\text { innovation capabilities }\end{array}$ \\
\hline $\begin{array}{l}\text { 3- Planning approach is not } \\
\text { iterative }\end{array}$ & & $\begin{array}{l}\text { Difficulties to speed up the } \\
\text { progress; low innovation } \\
\text { capabilities; low Visibility }\end{array}$ \\
\hline $\begin{array}{l}\text { 6- Not apply project plan } \\
\text { monitoring and updating } \\
\text { weekly or bi-weekly }\end{array}$ & $\begin{array}{l}\text { Help in improving the speed and } \\
\text { changeability of the project that can } \\
\text { mitigate the high-cost risk of late } \\
\text { changes. As well as working in short } \\
\text { iterations allow better time and } \\
\text { resource estimation for the required } \\
\text { tasks [10] }\end{array}$ & $\begin{array}{l}\text { Difficulties to speed up the } \\
\text { progress; low Visibility }\end{array}$ \\
\hline \multicolumn{3}{|l|}{ Enablers gaps } \\
\hline $\begin{array}{l}\text { Not a Project-oriented } \\
\text { structure }\end{array}$ & $\begin{array}{l}\text { Help to have fully dedicated project's } \\
\text { teams. Which improve their focus and } \\
\text { commitment [19] }\end{array}$ & $\begin{array}{l}\text { Difficulties to speed up the } \\
\text { progress; low innovation } \\
\text { capabilities }\end{array}$ \\
\hline $\begin{array}{l}\text { NPD process not Partially } \\
\text { standardized }\end{array}$ & $\begin{array}{l}\text { Partially standardized process helps to } \\
\text { align product development processes } \\
\text { to fit innovative project needs [19] }\end{array}$ & $\begin{array}{l}\text { Low innovation capabilities; } \\
\text { low Visibility }\end{array}$ \\
\hline $\begin{array}{l}\text { Supplier/partmer are not } \\
\text { involved in all stages }\end{array}$ & $\begin{array}{l}\text { Involvement in all stages help to obtain } \\
\text { faster feedback [19] }\end{array}$ & $\begin{array}{l}\text { Difficulties to speed up the } \\
\text { progress; Low Visibility }\end{array}$ \\
\hline $\begin{array}{l}\text { Team members are not } \\
\text { dedicated Full time or more } \\
\text { than } 75 \%\end{array}$ & \multirow{2}{*}{$\begin{array}{l}\text { Full dedication and co-location team } \\
\text { helps to obtain better focus on the } \\
\text { work, commitment, creativity, and } \\
\text { interaction between team members } \\
\text { [19] }\end{array}$} & $\begin{array}{l}\text { Difficulties to speed up the } \\
\text { progress }\end{array}$ \\
\hline $\begin{array}{l}\text { Team members are not } \\
\text { located in the same room }\end{array}$ & & Low innovation capabilities \\
\hline
\end{tabular}




\section{Conclusions}

This paper presents a series of challenges related to product development during turbulent times in three MFIs in Republic of Yemen. As well as identifies several rooms of improvements that APM could help in. Generally, this research work has been focusing on introducing APM to nonsoftware institutions in Yemen as a potential solution for these institutions to cope with the current environment turbulences and improve their performance.

Moreover, this study was conducted with only three MFIs in Yemen due to the time limits, further research for testing the framework is required with more MFIs or with other service institutions. Also, conducting action research is recommended too.

In addition, this study did not discuss and did not investigate the application of APM on the risk management practices. Since the risk management is recognized by the literature as an important aspect in institutions resilience [4], further research may be needed to investigate if APM can help in improving the institution's ability to manage/mitigate the surroundings risks during crisis times.

\section{REFERENCES}

[1] R. G. Cooper, C. J. Easingwood, S. Edgett, E. J. Kleinschmidt, and C. Storey, "What distinguishes the top performing new products in financial services," The Journal of Product Innovation Management, vol. 11, no. 4, pp. 281-299, 1994.

[2] S. Cedergren, A. Wall, and C. Norström, "Evaluation of performance in a product development context," Business Horizons, vol. 53, no. 4, pp. 359-369, 2010.

[3] K. T. Ulrich and S. D. Eppinger, "Development Processes and Organizations," in Product Design and Development, 2011, pp. 11-32.

[4] A. Wieland and C. Marcus, "The influence of relational competencies on supply chain resilience: a relational view," International Journal of Physical Distribution \& Logistics Management, vol. 43, no. 4, pp. 300-320, 2013.

[5] PMI, "The High Cost of Low Performance: PMI Pulse of Profession," 2014.

[6] P. Kettunen, "Agile software development in large-scale new product development organization: team-level perspective," (Doctoral Dissertation, Helsinki University of Technology), 2009.

[7] A. F. Sommer, C. Hedegaard, I. Dukovska-Popovska, and K. Steger-Jensen, "Improved Product Development Performance through Agile/Stage-Gate Hybrids," Research Technology Management, vol. 58, no. 1, pp. 34-44, 2015.

[8] T. Gustavsson, "Benefits of Agile Project Management in a Non- Software Development Context - A Literature Review," Fifth International Scientific Conference on Project Management in the Baltic Countries, no. April 2016.

[9] R. Cooper, "Agile - Stage-Gate Hybrids: The Next Stage for Product Development," ResearchTechnology Management, vol. 6308, no. January, pp. 21-28, 2016.

[10] N. Ovesen, "The Challenges of Becoming Agile: Implementing and Conducting SCRUM in Integrated Product Development," (Doctoral dissertation, Aalborg University), 2012.

[11] J. Sutherland and K. Schwaber, "The Scrum Papers: Nuts, Bolts, and Origins of an Agile Process," Scrum inc, 2011.

[12] The Social Fund for Development, "The Impact of the 2015 Conflict in Yemen on the Local Microfinance Industry,” 2015.

[13] A. S. Alshebami and V. Rengarajan, "Microfinance Institutions in Yemen "Hurdles and Remedies," International Journal of Social Work, vol. 4, no. 1, pp. 10-21, 2017.

[14] E. H. AboHulaika and V. N. Laturkar, "Microfinance in Yemen: Challenges and Opportunities," Imperial Journal of Interdisciplinary Research (IJIR), vol. 2, no. 6, pp. 472-481, 2016.

[15] A. S. Alshebami and M. Kandare, "Microfinance in Yemen "Challenges and Opportunities "," IJMSS, vol. 2, no. 12, pp. 400-413, 2014. 
[16] A. A. Homaid, A. Y. Zain, Y. A. Al-matari, M. S. Minai, and F. Bin Ahmad, "The Role of customerfocused strategies to improve islamic microfinance institutions performance: Empirical evidence and lessons from Yemen," International Review of Management and marketing, vol. 7, no. 1, pp. 291299, 2017.

[17] A. A. Qatinah, "Factors Affecting Microfinance Demand and Supply Gaps in Yemen," (Master Thesis, Phillipps University of Marburg), 2013.

[18] N. Jakobi and W. Kinyori, "Understanding National Culture's Influence on Product Innovation Approaches," (Master Thesis, Umea university), 2012.

[19] E. Conforto, F. Salum, D. C. Amaral, S. L. da Silva, and L. F. M. de Almeida, "Can Agile Project Management Be Adopted by Industries Other than Software Development?" Project Management Journal, vol. 45, no. July, pp. 21-34, 2014.

[20] M. Brand, The MBP Guide to New Product Development. ACCION International, 2001.

[21] CGAP, Product Development for Microfinance Institutions. Consultative Group to Assist the Poor CGAP, 2009.

[22] G. A. N. Wright, M. Brand, Z. Northrip, M. Cohen, M. McCord, and B. Helms, "Looking Before You Leap: Key Questions That Should Precede Starting New Product Development," Journal of Microfinance, vol. 4, no. 1, pp. 1-15, 2002.

[23] A. Jetter and F. Albar, "Project Management in Product Development: Toward a Framework for Targeted Flexibility," 2015 Proceedings of PICMET '15: Management of the Technology Age, pp. $1562-1575,2015$.

[24] R. Cooper, "Perspective: The Stage-Gate idea to launch process - Update, what's new and nexgen systems," Journal of Product Innovation Management, vol. 25, no. 3, pp. 213-232, 2008.

[25] J. Sutherland and N. Ahmad, "How a Traditional Project Manager Transforms to Scrum: PMBOK vs. Scrum," Presented paper at Agile 2011, Salt Lake City, pp. 1-7, 2011.

[26] A. Stare, "Agile project management in product development projects," Procedia - Social and Behavioral Sciences, vol. 119, pp. 295-304, 2014.

[27] M. Fowler and J. Highsmith, "The agile manifesto," Software Development, vol. 9, no. August, pp. 28-35, 2001.

[28] J. Shore and S. Warden, The Art of Agile Development, Second edition. Sebastopol: O'Reilly Media, Inc., 2008.

[29] J. Highsmith, "Innovative Product Development," in Agile Project Management: Creating Innovative Products, 2004, pp. 1-28.

[30] P. Abrahamsson, J. Warsta, M. T. Siponen, and J. Ronkainen, "New Directions on Agile Methods: A Comparative Analysis," Proceedings of the 25th International Conference on Software Engineering, pp. 244-254, 2003.

[31] A. Nasehi, "A quantitative study on critical success factors in agile software development projects; case study IT company," (Master thesis, University of Boras), 2013.

[32] R. Cooper and A. F. Sommer, "The Agile Stage-Gate Hybrid Model: A Promising New Approach and a New Research Opportunity," Journal of Product Innovation Management, vol. 33, no. 5, 2016.

[33] K. Schwaber and J. Sutherland, “The Scrum Guide," Scrum.Org and ScrumInc, no. July, p. 17, 2016.

[34] D. K. Rigby, J. Sutherland, and H. Takeuchi, "Embracing agile," Harvard Business Review, no. May, pp. 41-50, 2016.

[35] E. Conforto and D. C. Amaral, "Agile project management and stage-gate model-A hybrid framework for technology-based companies," Journal of Engineering and Technology Management JET-M, vol. 40, no. 2015, pp. 1-14, 2015.

[36] A. E. Akgün and H. Keskin, "Organisational resilience capacity and firm product innovativeness and performance,” International Journal of Production Research, vol. 52, no. 23, pp. 6918-6937, 2014.

[37] H. Carvalho, S. Azevedo, and V. Cruz-Machado, "Agile and resilient approaches to supply chain management: influence on performance and competitiveness," Logistics research, vol. 4, pp. 49-62, 2012.

[38] J. McCann, J. Selsky, and J. Lee, "Building Agility, Resilience and Performance in Turbulent Environments," People and Strategy, vol. 32, no. 3, 2009.

[39] J. W. Creswell, Qualitative inquiry\& research design - Choosing Among Five Approaches, Second Edi. Thousand Oaks: SAGE Publications, 2007.

[40] R. K. Yin, Case study research. Design and Methods, 5th edition. Thousand Oaks: SAGE Publications, 2014. 
International Journal of Software Engineering \& Applications (IJSEA), Vol.10, No.1, January 2019

[41] D. R. Cooper and P. S. Schindler, Business research methods, Twelfth edition. McGraw-Hill/Irwin, 2014.

[42] R. Ørngreen and K. Levinsen, "Workshops as a Research Methodology," The Electronic Journal of eLearning, vol. 15, no. 1, pp. 70-81, 2017.

[43] M. Brand, "New Product Development for Microfinance: Evaluation and Preparation Technical Note Number 1," ACCION International, 1998.

[44] S. Kapoor and G. Sinha, "Factors influencing new product development in microfinance institutions: A perspective from north Indian microfinance institutions," Journal of Innovation Economics \& Management, vol. 11, no. 1, p. 83, 2013.

[45] R. Cooper and A. F. Sommer, "Agile-Stage-Gate: New idea-to-launch method for manufactured new products is faster, more responsive," Industrial Marketing Management, 2016.

[46] M. Cohn, Succeeding with Agile Software Development Using Scrum. Boston: Pearson Education, 2010.

[47] M. Drury-grogan, "Performance on Agile Teams: Relating Iteration Objectives and Critical Decisions to Project Management Success factors," Information and Software Technology, vol. 56, no. 5, pp. 506-515, 2014.

[48] T. Vedsmand, S. Kielgast, and R. Cooper, "Integrating Agile with Stage-Gate ${ }^{\circledR}$ - How New AgileScrum Methods Lead to Faster and Better Innovation," innovationmanagement.se, pp. 1-15, 2016.

\section{AUTHORS}

Nabeel T. Alsohybe, is working as an Associate Professor at the Faculty of Computer and Information Technology, Sana'a university, Republic of Yemen. He received his BS degree in Computer Science from San Jose State University, MS degree in Telecommunication Systems Management from National University, and $\mathrm{PhD}$ in Organization and Management, Information Technology Management from Capella University, USA.

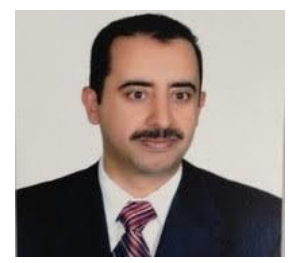

Nashwan Sabrah, Holding a Master degree in Business Administration, Lebanese International University, Sana'a, Yemen, 2018. Scrum-Master, open source advocate and the co-founder of http://nvf.ngo foundation.

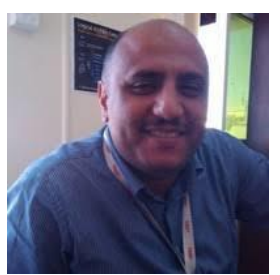

